\title{
PROFESSOR MARY HISCOCK
}

Mary came to Bond Law School after a long career at the University of Melbourne Law School where she had been Reader, Deputy Dean, and prominent in University life. She was one of Australia's first woman law teachers.

She graduated in 1961 from Melbourne where she was taught by a very strong faculty which included Zelman Cowen, Norval Morris, David Derham, Pat Donovan, Harold Ford, and Robin Sharwood as full-time staff, and a number of Victorian judges as part timers. The Honours degree was then obtained by a final three-day examination of the whole course. There was only one elective subject, and there were few Australian texts. Although criticized by Owen Dixon for its Americanisms, it was the leading law school in Australia teaching by case method, with an active mooting program, and legal aid involvement through the Brotherhood of St Laurence. It regularly had distinguished overseas visiting faculty. Mary was on the Editorial Board of the Melbourne University Law Review, which gave her close interaction with the staff.

Mary tutored until 1962 when she obtained Ford and Fulbright fellowships to study for a JD at the University of Chicago. There she was 
taught by a remarkable faculty which included Max Rheinstein, Soia Mentschikoff, and Malcolm Sharp. Rheinstein brought to the study of law a wealth of European culture. Soia Mentschikoff, the widow of Karl Llewellyn, had amazing intellect and strong views She normally taught Commercial Transactions, but taught Mary International Law. Sharp was a brilliant contract lawyer who gave Mary, coming from an Australian Catholic background, her first introduction to a coherent secular world view. Classes in the JD electives were small, 12-15 in a class. Having declined an offer of a job with a New York Wall Street law firm, Mary returned and was appointed to the Turner Special Lectureship at Melbourne. Some members of the profession were not happy with this as she was not an admitted barrister or solicitor. The students were, however, supportive and she overcame the opposition. Young law teachers then had to teach many subjects, but she had strong support from good colleagues like Zelman Cowen and Frank Maher. When a tutor, she started a LL.M by thesis on the scope of the external affairs power but, like most other tutors of the time, never finished her thesis.

In the 1960s, she began her long involvement in professional matters, and was the chair of the Women Lawyers Association in Victoria at the time of the first national Equal Pay Case. The Association prepared the case in support of the National Council of Women. It and the Australian Council of Trade Unions were the parties of record. She also began to 
develop her major interests in comparative law and international trade law. On the retirement of Hans Leyser at Melbourne, she turned what had been a European-based course in comparative law into one that used Asian legal materials. She also began to work with the federal government and the Solicitor-General, Bob Ellicott, in the field of international trade law, and was a significant force in the introduction of the annual Attorney-General's International Trade Law Seminar. She represented Australia on several occasions at UNCITRAL.

Mary met David Allan in the mid 1960s, and they developed their shared interest in Asian contract and securities law, which led to a long and fruitful collaboration. Throughout the 1970s, the team included Derek Roebuck. Together, Mary and David became very well-known in East and Southeast Asia for their work, and they served as external examiners in Hong Kong and Malaysia. They co-authored many books, including one on the law of contract.

All was not well in the Law School in the 1980s and Mary, after a bout of serious illness and some feelings of frustration, decided to seek her long-delayed admission as a barrister and solicitor. She served articles with Mallesons Stephen Jaques and found the experience challenging and invigorating. The Supreme Court abridged her articles, but this decision 
was challenged on appeal by the Board of Examiners. It became a leading case - a faint echo of the town-gown clashes of her appointment.

Mary has continued to have strong international connections and served as President of the International Academy of Commercial and Consumer Law in 1999 and 2000, and chaired the International Law Section of the Law Council of Australia from 1995 - 2002.

She was persuaded to accept the offer of a Chair of Law at Bond in 1993 when I became Dean, and she served as Associate Dean (Research and Graduate Studies) from 1994-1997. She has served with distinction and made a strong contribution to the University, both in terms of teaching Contract and International Trade Law, and in serving on University Committees. She chaired the inaugural Research Committee for many years. She reckons that, at Bond, she has experienced some of the best students and most supportive colleagues of her career. Bond has also managed to replicate the smaller classes of her early career and has given her a sense of teaching satisfaction once more.

She retired in 2002, and was made Emeritus Professor, but she continues to teach and supervise postgraduate students. Long may she do so.

John Farrar 